\title{
THE INFLUENCE OF PRODUCT INNOVATION, MARKET ORIENTATION AND ORGANIZATIONAL CULTURE ON BUSSINESS PERFORMANCE WITH THE COMPETITIVE ADVANTAGE AS INTERVENING VARIABLE: EMPIRICAL STUDY OF AGRICULTURAL CREATIVE INDUSTRY MSMES AT BOJONEGORO REGENCY OF EAST JAVA, INDONESIA
}

\author{
Nilasari Narida*, Student \\ Wanto Hary Sastrya, Susilo Achmadi, Lecturers \\ Magister's Study Program of Agribusiness, Faculty of Agriculture, Wijaya Kusuma University, \\ Surabaya, Indonesia \\ *E-mail: harysastryawan@gmail.com
}

\begin{abstract}
This study is intended to analyze the effect of Product Innovation, Market Orientation and Organizational Culture on Business Performance with Competitive Advantage intervening variable. The research, which was conducted in Bojonegoro Regency, East Java, involved entrepreneurs in the creative industries of agriculture, craft and culinary. Methodology, the method of collecting data is by interviewing and distributing questionnaires to 100 business actors using the Probability Sampling technique with a systemic random sampling system. The results of the questionnaire answers are given a scale according to the Likert Scale with a score of 1-5. Furthermore, the data were analyzed using SEM calculations with SmartPLS version 3.0 software. The data were analyzed by Influence Analysis with the Measurement Model (Outer Model) and Structural Model (Inner Model). The results of the study: Product Innovation variable has no significant effect on business performance. But Product Innovation has a higher level of influence on Business Performance if it is driven by the intervening variable of competitive advantage, although the results are positive but not significant. The Market Orientation variable has no significant effect on business performance directly or after being driven by the competitive advantage variable. It even results in a smaller value. Organizational culture has a positive and significant direct effect on business performance without being driven by the intervening variable Competitive advantage. If it involves Competitive Advantage Intervening Variables, it produces a negative relationship. From the results obtained, the Government of Bojonegoro Regency is expected to be even more aggressive in efforts to empower MSMEs in the Agricultural Creative Industry. So that in the future these SMEs can play a more significant role in turning the wheels of the economy in Bojonegoro Regency.
\end{abstract}

\section{KEY WORDS}

Product innovation, market orientation, organizational culture, competitive advantage, business performance.

The new era of globalization is currently marked by a big leap in information and communication technology known as the industrial era 4.0. Digitization is the key word in this era. The Industrial Revolution 4.0 has also given birth to a new business sector known as the Creative Industry. Creative industries that are developing in Indonesia are mostly dominated by Micro, Small and Medium Enterprises (MSMEs). MSMEs, even though they have the ability to adapt to the business environment and are flexible so they are more able to survive, still have many obstacles in their development efforts. Competition in the business world forces business actors to understand their business environment both internally, namely organizational culture and externally, namely market conditions, including understanding the products that consumers want. It is intended that the company is able to compete so as to improve its business performance. Zimmerer and Scarborough (2005) state that to win the competition, it is not enough just to build a competitive advantage. But how to build competitive advantage sustainably. The success of a company depends on the strategies 
generally used by the company, namely market orientation and product innovation. In accordance with what Drucker (1999) said that business and technological changes are threatening organizational sustainability and modern management faces many challenges. Organizations are continually under competitive pressures and forced to re-evaluate come up with new innovations. An innovation can be a new product or service, a new production technology, a new product operating procedure or a new management strategy for a company

Bojonegoro Regency is one of the regencies that have a large number of creative industry business actors. According to the records of the Department of Industry, Trade and Manpower, there are 13,598 creative industry business units in Bojonegoro Regency. Of this amount, 90.14 percent was dominated by the agribusiness sector, which consisted of 6,478 units or 47.64 percent occupied by the creative craft industry (crafts), 5,780 units or 42.50 percent occupied by the culinary business sector. This Creative Industry is spread in villages by utilizing the superior potential that exists in the village. Managed as a home industry, the scale of this business sector is included in the category of Micro, Small and Medium Enterprises (MSMEs).

As a region whose economic growth is currently dependent on the oil and gas sector, in the future the Creative Industry business sector is expected to be able to replace the role of the oil and gas sector to hold the baton in supporting economic growth and be able to become the main contribution to forming the GRDP figure of Bojonegoro Regency. In addition, the development of Creative Industry MSMEs is expected to be a solution to employment problems in Bojonegoro.

So important is the position and role of the Creative Industry in Bojonegoro Regency, so this research is intended to find out how the Creative Industry's Business Performance in Bojonegoro Regency is by using Product Innovation, Market Orientation and Organizational Culture analysis tools with Competitive Advantage intervening variables.

\section{LITERATURE REVIEW}

According to Kotler and Keller (2016; 476) product innovation is "An innovation is any good, service, or idea that someone perceives as new, no matter how long its history, the spread of a new idea from its source of invention or creation to its ultimate users or adopters". This product innovation can be divided into three categories: 1) Product Line Extension These are products that are relatively new to the market but not new to the company. 2) "me too" products are products that are relatively new to the company but the market is familiar with them first. 3) "new to the world" products. It is a completely new product for both the market and the company.

Market orientation is an implementation of marketing theory. Day (1988) argues that market orientation reflects competence in understanding customers. Agreeing with Day, Craven (1994) sees market orientation as setting strategic consumer targets and building an organization that focuses on customer service, providing a competitive basis that focuses inward, providing services that meet consumer expectations, so as to win a competition. Therefore, marketing orientation requires proper attention to customer orientation and competitor orientation in order to provide the needs and wants of consumers by providing the best value (Lamb et al., 2001). Narver and Slater (1990) summarized that market orientation consists of three behavioral components: (1) customer orientation, (2) competitor orientation and (3) interfunctional coordination and two decision criteria including profit targets and longterm focus. Robbins and Timoty (2008:256) define organizational culture as a system of shared meanings (perceptions) held by members of the organization, which distinguishes the organization from other organizations. Meanwhile, Luthans (2006:137) defines organizational culture as a basic thought pattern that is taught to new personnel as a way to feel, think, and act correctly from day to day. Davis (1989) in Moeheriono (2012:336) argues that organizational culture is a pattern of organizational beliefs and values that are understood, inspired, and practiced by the organization so that the pattern gives its own meaning and becomes the basis for the rules of behavior in the organization. 
From several definitions of organizational culture according to the experts above, it can be concluded that organizational culture is a collection of values and attitudes that can be believed and accepted or rejected by all members of the organization as a feature of the organization and can be used as guidelines for behavior in achieving the goals of the organization.

The basic thinking of creating a competitive strategy begins with a desire about how the business will be developed, what its goals are and what policies will be needed to achieve these goals (Droge and Vickrey, 1994). Barney (2008) argues that companies will be able to achieve competitive advantage if the company implements a value creating strategy that is not done by other companies at the same time. According to Setiawan \& Ine Agustin (2008) competitive advantage arises when consumers think that they receive more value from the transactions they do compare to a competitor. Porter (1990) reveals that competitive advantage develops from the value a company is able to create for its customers. Porter's (1980) theory states that the indicators of competitive advantage are divided into cost leadership, differentiation and focus.

Business performance refers to the results, namely the level of achievement or achievement of a business entity within a certain period of time. The company's goals, which consist of: remain standing or exist (survive), to earn a profit (benefit) and can develop (growth), can be achieved if the company has good performance. Various studies say there are various measures to see the results of company performance. From these various measures, it can be concluded that there are two aspects, namely using financial aspects such as income, cash flow, asset returns and returns on capital (Lee and Yu, 2004) and nonfinancial aspects (market reach, number of employees and additional outlets/subsidiaries). Meanwhile, non-financial performance includes market share, company growth, customer satisfaction, customer loyalty and brand equity (Lumpkin and Dess, 1996; Clark, 1999; Haber and Reichal, 2005).

Hypothesis:

- $\mathrm{H} 1, \mathrm{H} 3, \mathrm{H} 5$ : Variables of product innovation, market orientation and organizational culture directly influence significantly on business performance;

- H2, H4, H6: Variables of product innovation, market orientation and organizational culture indirectly influence significantly on business performance through competitive advantage as intervening variable;

- $\quad \mathrm{H} 7$ and H8: Simultaneously, product innovation, market orientation and organizational culture have a significant effect on Business Performance directly and indirectly through Competitive Advantage as an Intervening Variable.

\section{METHODS OF RESEARCH}

The determination of the sample in this study was carried out using a probability sampling technique with a systemic random sampling system. The respondent's target is the creative industry entrepreneurs of Agricultural SMEs in Bojonegoro Regency, number of respondents 100 people. This is in accordance with the opinion of Ferdinand, 2005 that in SEM (Structural Equation Modeling) research is a minimum of 100 samples. The technique used to collect data is by interviewing, observing and distributing closed questionnaires. The instrument given to respondents using a 5-point Likert scale technique to measure research variables.

Table 1 - Alternative of Answer

\begin{tabular}{|l|l|l|}
\hline Product Innovation Variable & Market Orientation, organizational culture, competitive advantage \\
\hline Very Often & Strongly Agree & Likert \\
\hline Often & Agree & 5 \\
\hline Quite Often & Somewhat Agree & 4 \\
\hline Not Often & Disagree & 3 \\
\hline Very Not Often & Strongly Disagree & 2 \\
\hline
\end{tabular}

Source: Likert Scale. 
The data analysis technique will use SEM (Structural Equation Modeling) or Structural Equation Modeling with the AMOS 4 program. The software used to process this data is AMOS 4 and the PLS program. The help of the SmartPLS software version 3.0 for windows as a descriptive statistical measurement tool. Establishing a research model based on theoretical justification that forms a causal relationship from the construct (variable) of the research model, in this study there is a variable construct consisting of three exogenous constructs, namely Product Innovation, Market Orientation and Organizational Culture and one Endogenous variable construct, namely business performance, and the competitive advantage intervening variable.

\section{RESULTS AND DISCUSSION}

Measurement models refer to the implicit or explicit models that relate the latent variable to its indicators. There are Validity and Reliability test. After testing the first model by PLS, the results are:

The Product Innovation variable (X1). There is produces a loading value above 0.5 , meaning that all indicators on the Product Innovation variable are feasible to use because they meet convergent validity.

Market Orientation Variable (X2). There are 3 indicators that have a loading factor below 0.5 , namely OP1 (-0.083), OP2 (0.096) and OP3 (0.068). So that the three indicators are better removed from the model.

Organizational Culture Variable (X3). There is 1 indicator that has a loading factor value below 0.5 , namely BO1 (-0.196), so it must be removed from the model.

Business Performance Variable $(Y)$. There are three indicators that have a loading factor value below 0.5 , namely KU1 (0.009), KU2 (-0.502) and KU4 (-0.532). So that the three indicators are considered to have a low level of validity so they must be removed from the model

Competitive Advantage Variable ( $Z$ ). All indicators have a loading factor value above 0.5 so that it can be interpreted that all indicators on the Competitive Advantage $(Z)$ variable have a high level of validity so that they meet convergent validity.

Due some indicators still have loading factor $<0.5$, it must be removed from the model. After removing those indicators a new PLS SEM model can be obtained which shows all indicators already have a loading factor value above 0.5 . So that it is considered to have a high level of validity and meets convergent validity and then discriminant validity will be tested.

From the results of the cross loading count on the Product Innovation variable, it shows that the loading value of each indicator on its construct $(\mathrm{X} 1)$ is greater than the cross loading value. So it can be concluded that all constructs or latent variables already have good discriminant validity.

The calculation results on the $\mathrm{X} 2$ (Market Orientation) variable, there are three indicators, each OP1 (-0.083), OP2 (0.096), OP3 (0.068) which has a value smaller than the cross loading value. From the results of the crossloading analysis, the indicators OP1, OP2 and OP3 were removed from the model.

The result of the calculation on the $\mathrm{X} 3$ variable (Organizational Culture) there is one indicator, namely BO1 $(-0.196)$ which has a value smaller than the cross loading value, namely the Competitive Advantage variable (-0.032). From the results of the crossloading analysis, the BO1 indicator is removed from the model.

From the results of the SEM-PLS calculation, the cross loading on the Competitive Advantage variable $(Z)$, shows that the loading value of each indicator on the construct $(Z)$ is greater than the cross loading value. So it can be concluded that all the constructs or latent variables of Competitive Advantage already have good discriminant validity.

From the calculation results of the Business Performance Variable $(Y)$, there are 3 indicators whose loading value is smaller than the cross loading value. So it can be concluded that this business performance variable does not meet the requirements of discriminant validity. So the three indicators must be removed from the construct 
Due some indicators still have a smaller cross loading value than indicators of other variables; it must be removed from model. Next, the new model shows a good model.

Table 2 - Composite Reliability

\begin{tabular}{|l|l|}
\hline $\mathrm{n} / \mathrm{n}$ & Composite Reliability \\
\hline Organizational Culture & 0,980 \\
\hline The Product Innovation & 0,944 \\
\hline Competitive Advantage & 0,875 \\
\hline Business Performance & 1,000 \\
\hline Market Orientation & 0,874 \\
\hline
\end{tabular}

Source: Primary Data Analysis.

Table 3 - Cronbach's Alpha

\begin{tabular}{|l|l|}
\hline $\mathrm{n} / \mathrm{n}$ & Cronbach's Alpha \\
\hline Organizational Culture & 0,978 \\
\hline The Product Innovation & 0,938 \\
\hline Competitive Advantage & 0,838 \\
\hline Business Performance & 1,000 \\
\hline Market Orientation & 0,840 \\
\hline
\end{tabular}

Source: Primary Data Analysis.

The model shows Composite Reliability values above 0.7 and Cronbach's Alpha values above 0.6 , which means that all constructs have a good level of reliability because they have the required minimum value.

In PLS, in order to minimize the problem of abnormal research data, a test is carried out on each relationship in the sample using the Bootstrapping method. The test results using the bootstrapping method from the PLS SEM analysis are as follows:

Analysis of the Structural Model (Inner Model) was carried out to see and explain the relationship between latent variables in the study, namely exogenous variables and endogenous variables so that they were able to answer problems regarding the relationship between latent variables that had been hypothesized previously.

Inner Model analysis can be done by looking at the values of $R^{2}, Q^{2}$ and $F^{2}$.

Table 4 - R Square Analysis

\begin{tabular}{|l|l|}
\hline $\mathrm{n} / \mathrm{n}$ & $\mathrm{R}$ Square \\
\hline Competitive Advantage & 0,133 \\
\hline Business Performance & 0,103 \\
\hline
\end{tabular}

Source: Primary Data Analysis.

Simultaneously, the exogenous variables of product innovation, market orientation and cultural orientation have a direct influence on business performance by $10.3 \%$. It mean there are other variables that give an influence on business performance by $89.7 \%$ if through the intervening variable competitive advantage, the three exogenous variables have an effect on business performance of $13.3 \%$. It means there are other variables that give a indirect influence on business performance by $86.7 \%$.

$$
\mathrm{Q}^{2}=1-\left(1-\mathrm{R} 1^{2}\right)\left(1-\mathrm{R} 2^{2}\right)=0,028
$$

Due the value of $Q^{2}>0$, the model already has predictive relevance.

The result of $\mathrm{F}^{2}$ is that all of exogenous variables have a weak influence on endogenous variable.

Bootstrapping is a process to assess the level of significance or probability of direct effects, indirect effects and total effects. In addition, bootstrap can also assess the level of significance of other values, including: $r$ square and adjusted $r$ square, $f$ square, outer loading and outer weight. 


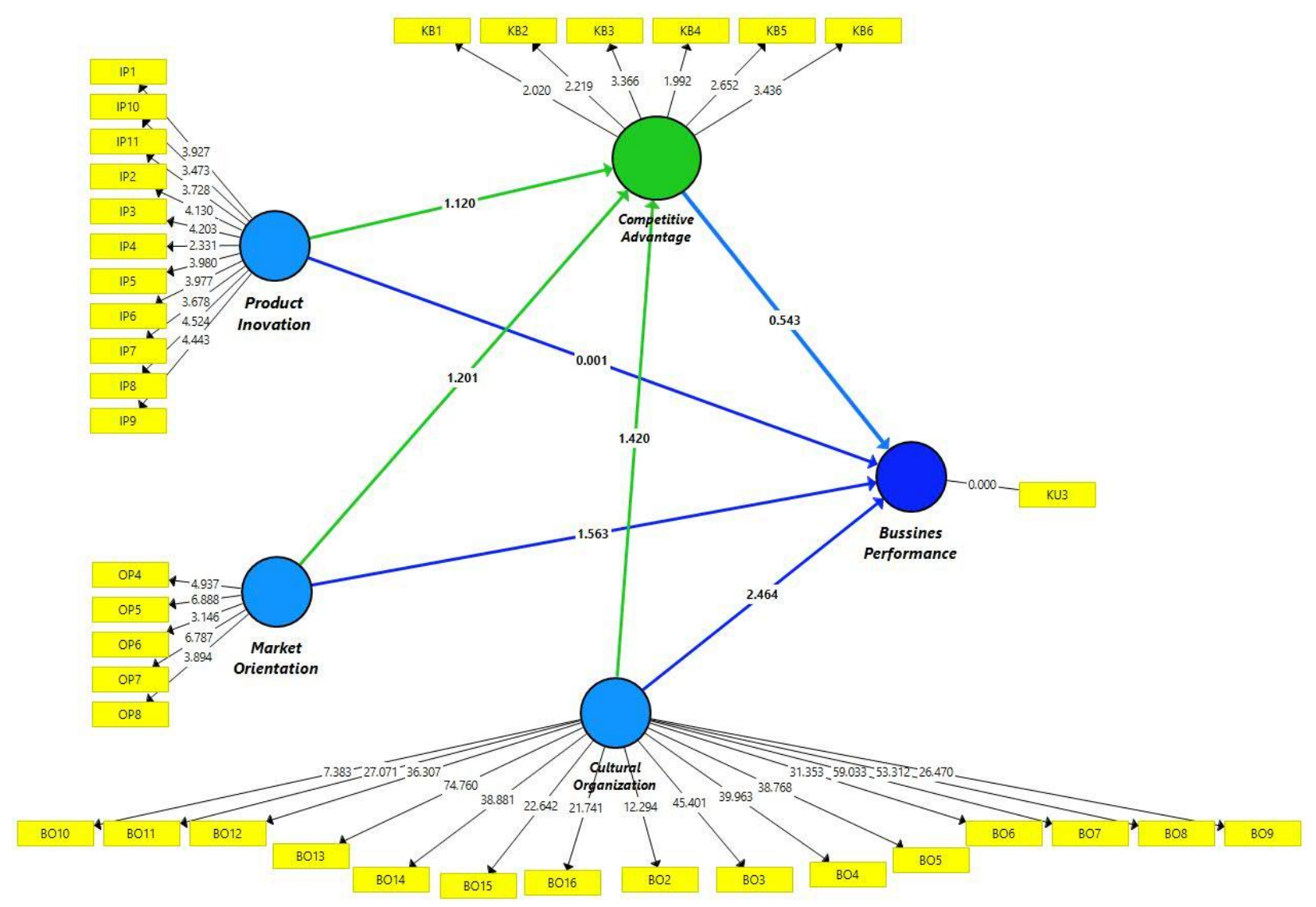

Figure 1 - Bootstrapping

\section{CONCLUSION}

The Product Innovation Variable has no significant effect on business performance directly or after being driven by the competitive advantage variable. The Market Orientation variable has no significant effect on business performance directly or after being driven by the competitive advantage variable. Organizational culture has a direct and significant effect on business performance and the effect becomes insignificant if it is through the intervening variable Competitive advantage. Simultaneously, the exogenous variables have no significant effect on Business Performance directly and indirectly through Competitive Advantage as an Intervening Variable the exogenous variables have no significant effect too.

\section{Suggestions:}

- Business actors must determine the right strategy according to the type of business and business environment in order to increase competitive advantage and business performance;

- The government through related agencies must move actively and synergize with each other by removing their respective sectoral egos.

\section{REFERENCES}

1. Anjaningrum, W. D., \& Sidi, A. P. (2018). Pengaruh Orientasi Pasar, Inovasi and Kreativitas Produk Terhadap Kinerja Industri Kreatif Untuk Mencapai Keunggulan Bersaing. Jurnal Ilmiah Bisnis and Ekonomi Asia, 12(2), 30-47. https://doi.org/10.32812/jibeka.v12i2.22.

2. Ariningsih, E. P. (2007). Pengaruh Budaya Organisasi Pada Kinerja Perusahaan. SEGMEN - Manajemen, (No 2 (2007): Jurnal Manajemen \& Bisnis). Retrieved from http://ejournal.umpwr.ac.id/index.php/segmen/article/view/87.

3. Ayuningrum, I. D., \& Pangestuti, E. (2018). Pengaruh Inovasi Terhadap Keunggulan 
Bersaing and Kepuasan Pengunjung Industri Pariwisata Di Kabupaten Bojonegoro. Jurnal Administrasi Bisnis, 60(1), 195-203.

4. Berman Surriadi. (2003). SME EMPOWERMENT IN SURABAYA: Case Study Jajan Pasar Association in District Tandes. 1(1), 6-8. https://doi.org/10.16309/j.cnki.issn.10071776.2003.03.004.

5. Bogdanowicz, M., \& Bogdanowicz, M. (n.d.). Organizational Culture As a Source of Competitive Advantage - Case Study of a. 53-66.

6. Haryono, T., \& Marniyati, S. (2018). Pengaruh Market Orientation, Inovasi Produk, and Kualitas Produk Terhadap Kinerja Bisnis Dalam Menciptakan Keunggulan Bersaing. Jurnal Bisnis and Manajemen, 17(2), 51. https://doi.org/10.20961/jbm.v17i2.17174

7. Hary Sastrya Wanto, *Ruswiati Suryasaputra, The Effect of Organizational Culture and Organizational Learning towards the Competitive Strategy and Company Performance (Case Study of East Java SMEs in Indonesia: Food and Beverage Industry), 467 Information Management and Business Review Vol. 4, No. 9, pp. 467-476, Sep 2012 (ISSN 2220-3796)

8. Jardon, C. M., \& Martínez-Cobas, X. (2019). Leadership and organizational culture in the sustainability of subsistence small businesses: An intellectual capital based view. Sustainability (Switzerland), 11(12). https://doi.org/10.3390/su10023491

9. Jayaningrum, E., \& Sanawiri, B. (2018). Pengaruh Orientasi Pasar, Inovasi, Orientasi Kewirausahaan Terhadap Keunggulan Bersaing and Kinerja Pemasaran. Jurnal Administrasi Bisnis (JAB), 54(1), 149-158.

10. Ketut, N., Satwika, P., Made, N., Kusuma, W., \& Free, A. (2018). Pengaruh Orientasi Pasar Serta Inovasi Terhadap Keunggulan Kompetitif and Kinerja Bisnis. 7(3), 14811509.

11. Library, U. I. (n.d.). Perkembangan teknologi dalam tinjauan Alvin Toffler.

12. Lumpkin, G. T., \& Dess, G. G. (1996). Clarifying the entrepreneurial orientation construct and linking it to performance. Academy of Management Review, 21(1), 135-172. https://doi.org/10.5465/AMR.1996.9602161568.

13. Morgan, T., \& Anokhin, S. A. (2019). The joint impact of entrepreneurial orientation and market orientation in new product development: Studying firm and environmental contingencies. Journal of Business Research. https://doi.org/10.1016/j.jbusres.2019.06.019.

14. Nayak, B., \& Barik, A. (2013). Assessment of the Link between Organizational Culture and Job Satisfaction (Study of an Indian Public Sector). International Journal of Advanced System and Social Engineering Research ISSN, 3, 2278-6031. Retrieved from http://www.bipublication.com.

15. Raharja, S. (2009). Kolaborasi Sebagai Strategi Bisnis Masa Depan. Jurnal Administrasi Bisnis Unpar, 5(1), 44-53. https://doi.org/10.26593/jab.v5i1.2102.

16. Sadri, G., \& Lees, B. (2001). Developing corporate culture as a competitive advantage. Journal of Management Development, 20(10), 853-859. https://doi.org/10.1108/02621710110410851.

17. Setiawan, H. (2006). Pengaruh Orientasi Pasar, Budaya Organisasi And Orientasi Kewirausahaan Terhadap Kinerja Usaha (Studi pada Usaha Kecil Pengolahan di Kota Palembang) Heri Setiawan 1.

18. Slater, S. F. (2000). The Positive Effect of a Market Orientation. Journal of Business Research 48, 48(98), 69-73.

19. Sukma, M. (2015). Kajian Pustaka (Literature Review) (Vol. 2, pp. 1-13). Vol. 2, pp. 113. https://doi.org/10.1017/CBO9781107415324.004.

20. Suparman, S., \& Ruswanti, E. (2017). Market Orientation, Product Innovation on Marketing Performance Rattan Industry in Cirebon Indonesia. IOSR Journal of Economics and Finance, 08(01), 19-25. https://doi.org/10.9790/5933-0801031925.

21. Supriyanto, A., Sukrina, H. R., \& Abidin, M. Z. (2017). Pengaruh Orientasi Pasar and Inovasi Produk Terhadap Keunggulan Bersaing (Studi pada UMKM Kopiah Haji di Kabupaten Hulu Sungai Tengah ) Akhmad Supriyanto ; Hipni Rahman Sukrina ; M. Zainal Abidin Program Studi Manajemen - Fakultas Ekonomi and Bisnis Uni. 27-28. 
22. Sutapa, S., Mulyana, M., \& Wasitowati, W. (2017). The Role of Market Orientation, Creativity and Innovation in Creating Competitive Advantages and Creative Industry Performance. Jurnal Dinamika Manajemen, 8(2), 152-166. https://doi.org/10.15294/jdm.v1i1.12756.

23. Usvita, M. (2015). Pengaruh Orientasi Kewirausahaan and Orientasi Pasar Terhadap Kinerja Perusahaan Melaluli Keunggulan Bersaing Sebagai Variabel Intervening (Survei Pada UKM Pangan Dinas Perindagtamben Kota Padang). E-Jurnal Apresiasi Ekonomi, Vol. 3, pp. 31-37.

24. Winda Ayu Lestari, Apri Budianto, I. S. (2020). Pengaruh Inovasi and Kualitas Produk Terhadap Keunggulan Bersaing (Suatu Studi pada Payung Geulis Mandiri Tasikmalaya). Business Management and Entrepreneurship Journal, 2, 38-48.

25. Yanuar, N. D., \& Harti, H. (2020). Pengaruh Inovasi Produk and Orientasi Pasar Terhadap Kinerja Penjualan Pada Home Industri Olahan Ikan Di Kabupaten Trenggalek. Jurnal Manajemen Pemasaran, 14(2), 51-60. https://doi.org/10.9744/pemasaran.14.2.51.

26. Zhou, K., Brown, J., \& Dev, C. (2009). Market orientation, competitive advantage, and performance: A demand-based perspective. Journal of Business Research, 62, 10631070. https://doi.org/10.1016/j.jbusres.2008.10.001. 